Review

\title{
Bioactive Secondary Metabolites from Plant Sources: Types, Synthesis, and Their Therapeutic Uses
}

\author{
Baan Munim Twaij ${ }^{1, *}$ and Md. Nazmul Hasan ${ }^{2}$ D \\ 1 Department of Biology, College of Science, Mustansiriyah University, Baghdad P.O. Box 10422, Iraq \\ 2 Department of Genetic Engineering and Biotechnology, Shahjalal University of Science and Technology, \\ Sylhet 3114, Bangladesh; nayeemsust15@gmail.com \\ * Correspondence: ban.twaij@yahoo.com; Tel.: +964-7713220286
}

Citation: Twaij, B.M.; Hasan, M.N. Bioactive Secondary Metabolites from Plant Sources: Types, Synthesis, and Their Therapeutic Uses. Int. J Plant Biol. 2022, 13, 4-14. https:// doi.org/10.3390/ijpb13010003

Academic Editor: Adriano Sofo

Received: 28 January 2022

Accepted: 10 February 2022

Published: 21 February 2022

Publisher's Note: MDPI stays neutral with regard to jurisdictional claims in published maps and institutional affiliations.

Copyright: (C) 2022 by the authors. Licensee MDPI, Basel, Switzerland. This article is an open access article distributed under the terms and conditions of the Creative Commons Attribution (CC BY) license (https:// creativecommons.org/licenses/by/ $4.0 /)$.

\begin{abstract}
Plants are the source of various photochemicals; metabolites are used in medicinal and environmental sectors as well as being widely used in commercial and pharmaceutical products. Although they produce a number of medicinal products, either already on the market or under trial, the amounts obtained from plant sources are very minute or difficult to synthesize at an industrial level due to the complex chemical composition and chirality exhibited by these compounds. However, plant cell cultures offer a good alternative for the consistent production of desired secondary metabolites under the influence of precursors and elicitors. In this review, we discuss the various aspects of secondary metabolites, production synthesis, and sources of medical products from plant sources.
\end{abstract}

Keywords: metabolites; medicinal effect; synthesis; precursor and elicitors

\section{Introduction}

Secondary metabolites are small organic molecules originated from primary metabolites during the embolism of plant; they essentially have molecular masses of less than $3000 \mathrm{da}$. The chemical nature and composition of metabolites in plants varies among species. There is no clear differentiation between primary and secondary metabolites and this is quite confusing to define, since most metabolites in natural products of plants are secondary metabolites. Secondary metabolites are interesting for various diverse reasons as, in the literature, they have been found to be interesting due to their structural diversity and their potency as a drug candidate and/or antioxidants. There are few examples of chemical diversity of plant metabolites, thus they are complexes that cannot be synthesized by the industry $[1,2]$.

The use of plant metabolites started as far back as $2600 \mathrm{BC}$, and in the following 4000 years, secondary metabolites originating from plants were used mainly for medicinal and poison purposes as well as food. Morphine was the first natural product isolated from the opium poppy (Papaver somniferum) in 1806 and it opened a new era in secondary metabolite research [1]. It was then established that plant extract activity is attributed to a single organic compound [3], which has its own individual identity and also can be purified. Thus, these research outcomes initialized natural product research and, to date, plant secondary metabolites have played a major role, which is demonstrated by the fact that more than $30 \%$ of medicinal products derive directly or indirectly from natural products [4-6]. In the past 100 years, there has been a rapid growth in plant metabolite research due to the availability of hi-tech research equipment.

The biological functions of metabolites were widely unrecognized due to the frequently low concentrations of metabolites in plants, and earlier, they were recognized as metabolic waste or detoxification products. Knowledge about secondary metabolites, known at earlier times for their toxic effects on animals cells, but later for their ecological importance and numerous other benefits, has emerged over the past four decades $[7,8]$. 


\section{Types of Secondary Metabolites}

Plants naturally produce a variety of products of different chemical natures, which are used for the growth and development of plants. Primary metabolites provide the supplies required for processes, such as photosynthesis, translocation and respiration. The products derived from primary metabolites, not directly involved in growth and development, are considered secondary metabolites. In general, secondary metabolites are the product of primary metabolites and are produced from biosynthesis modifications, including methylation, glycosylation and hydroxylation. Secondary metabolites are certainly more complex in structural composition and side chains compared to primary metabolites $[9,10]$.

There are three major classes of plant metabolites (Figure 1) based on the biosynthetic pathway: (i) phenolic groups (composed of simple sugars and benzene rings), (ii) terpenes and steroids (composed mainly of carbon and hydrogen), and (iii) nitrogen-containing compounds [11].

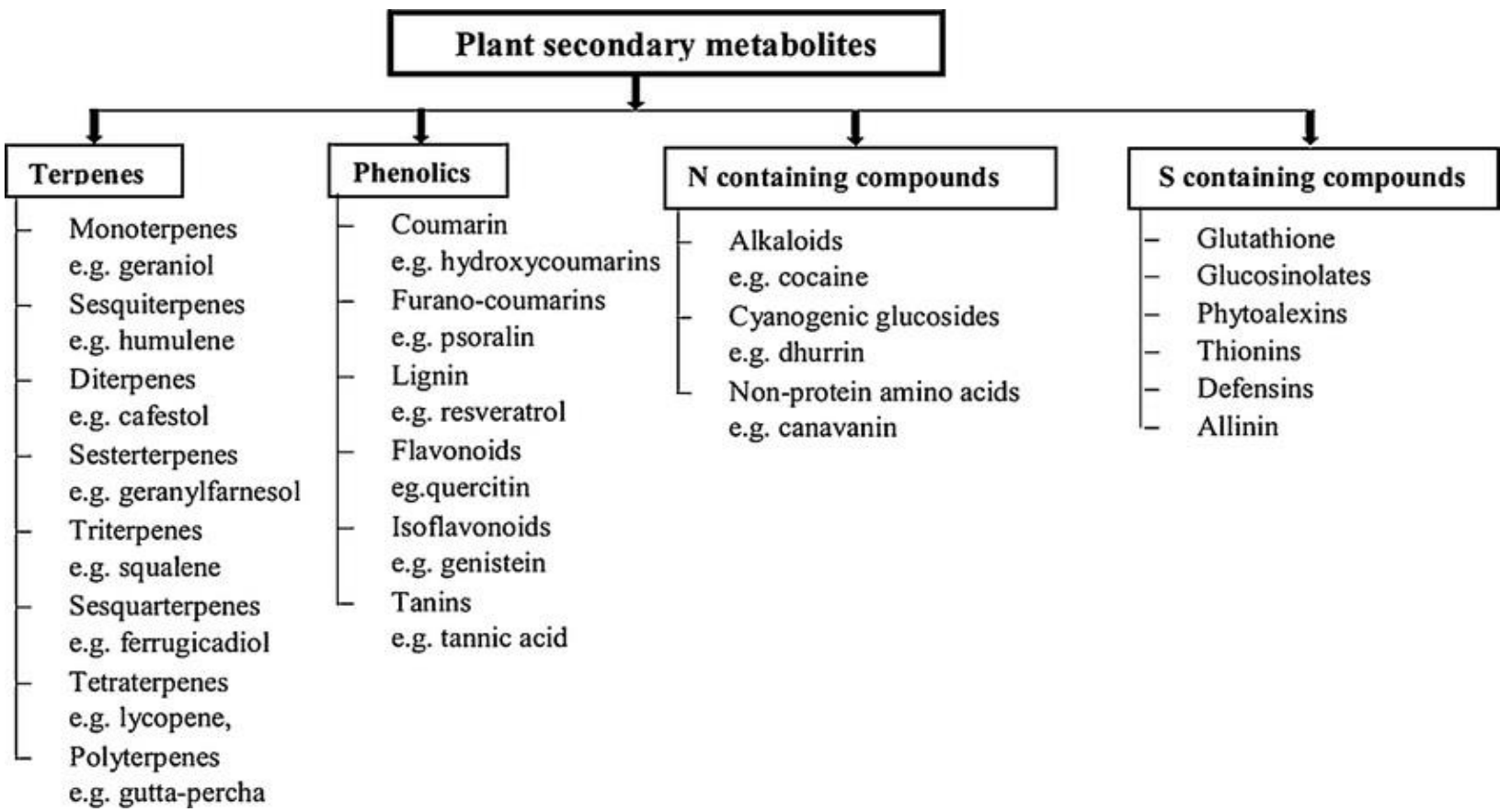

Figure 1. The four major types of secondary metabolites that have the major terpenes and phenolics.

Phenolic compounds derive from the phenylpropanoid pathway in plants and they have diverse structures and supply flowers, fruits and vegetables with color. Alkaloids and flavonoids are large groups of secondary metabolites with highly diverse biological functions. A variety of phenolic metabolites seems to have several properties, such as anti-oxidant, anti-carcinogenic and anti-inflammatory effects [12]. Alkaloids are other major metabolites that often have pharmacological and recreational effects. There is a third group of nitrogen-based organic compounds, which contain a heterocyclic ring of aromatic amino acids that is synthesized from the shikimic acid pathway. Interestingly, the aromatic amino acids phenylalanine and tryptophan are common metabolic precursors for both phenolic compounds and alkaloids [1].

\section{A Brief Description of Various Secondary Metabolites: Phenolic Compounds}

\subsection{Flavonoids}

To date, more than 4000 different flavonoids have been identified from plant origin. These are more commonly found in green plants [13], and are present mainly as glycosides in leaves, flowers, stems and roots. Flavonoids consist of two benzene rings [14]; thus, chalcones, flavones, flavanols, flavanones, anthocyanins, and isoflavones are major flavonoids that are often brightly colored [14]. 


\subsection{Phenylpropanoids}

Phenylpropanoids are only used by plants and microorganisms and derive from the shikimate pathway, producing essential aromatic amino acids, such as phenylalanine and tyrosine. As these are mostly required by animals and humans, plants become a part of the food chain for humans to obtain essential amino acids.

\subsection{Terpenes}

These are a structurally diverse and large metabolite group with at least more than 35,000 different terpenes having been characterized to date [15]. Terpenes consist of isoprene units that can be modified by cyclisation reactions, making them easily recognizable. They are classified in different groups based on the number of isoprene units in their carbon skeleton, as indicated in Figure 1 [16]. Terpenoids include metabolites with antitubercular [17], anticancer activities [15], anxiolytic, and mutagenic active molecules [18].

\subsection{N-Containing Compounds}

Alkaloids contain nitrogen in their cyclic organic compounds, but they have very limited presence in nature [19]. These are mostly soluble in aqueous solutions; thus, they are conveniently extracted in water upon the protonation of the nitrogen. This group have some of the most famous and infamous compounds, such as caffeine, nicotine, cocaine and morphine, which are known for their anxiolytic, analgesic and hallucinogenic effects [15], and often have physiological effects on the central nervous system. Although it is a small group of metabolites, $50 \%$ of plant-derived pharmaceuticals are alkaloids [20].

\section{Induction of Plant Secondary Metabolism and Production by Inducer and Precursor}

It has been broadly documented that plant-rich sources of a variety of secondary metabolites can be used for medicinal and therapeutic purposes and there have been efforts to commercialize the production for human benefit. However, sometimes it is not possible to use the biochemical synthesis pathway of secondary metabolites at an industrial level due to the complexity of the metabolic pathways; they are complicated structures to synthesize in a laboratory and the chirality exhibited by these compounds and most plants accumulates secondary metabolites in small amounts in specialized tissues in their life cycle (Figure 2). In that case, the production of such metabolites is enhanced in various ways. As these secondary metabolites are mainly regulated by the transcriptional activities of the gene cassette encoding particular enzymes in the biosynthetic pathway for desired products, the catalytically activities of these genes or enzymes are kept at very low levels naturally and gene active status can be triggered by the use of elicitors [21]. The exposure of plant cells to elicitors or precursors may also result in the accumulation of secondary products [22]. The most used and tested elicitors are jasmonic acid, and its methyl ester called methyl jasmonate, tryptophan, phenylalanine, and plant-specific messenger molecules originating from arachidonic acid [22]. Effective elicitors enhance the production of useful metabolites in plant cells via the upward regulation of the biochemical mechanisms by which these elicitors regulate the biosynthesis of the natural products. Although it is known which particular elicitors should be used for peculiar metabolites, one must know how an elicitor is recognized by plant cells and how the signals are transformed in cells expressing and controlling the biosynthesis of related genes to produce secondary metabolites. To explore these questions, attempts should be made to explore the biosynthetic pathway of secondary metabolites.

If the metabolite is not feasible to scale up through chemical synthesis, the only remaining option is to produce it through the enhancement of cell cultures, which include being treated with elicitors, precursors, and signaling compounds. Precursors are related compounds or intermediates of a secondary metabolite from the beginning of the biosynthetic pathway [23], such as Salvia officinalis and Taxus, which are cell suspension cultures that are stimulated by taxol production and rosmarinic acid, respectively, with the addition 
of phenylalanine [24,25]. Elicitors have been developed to improve the yield of secondary metabolites via signal triggering $[26,27]$.

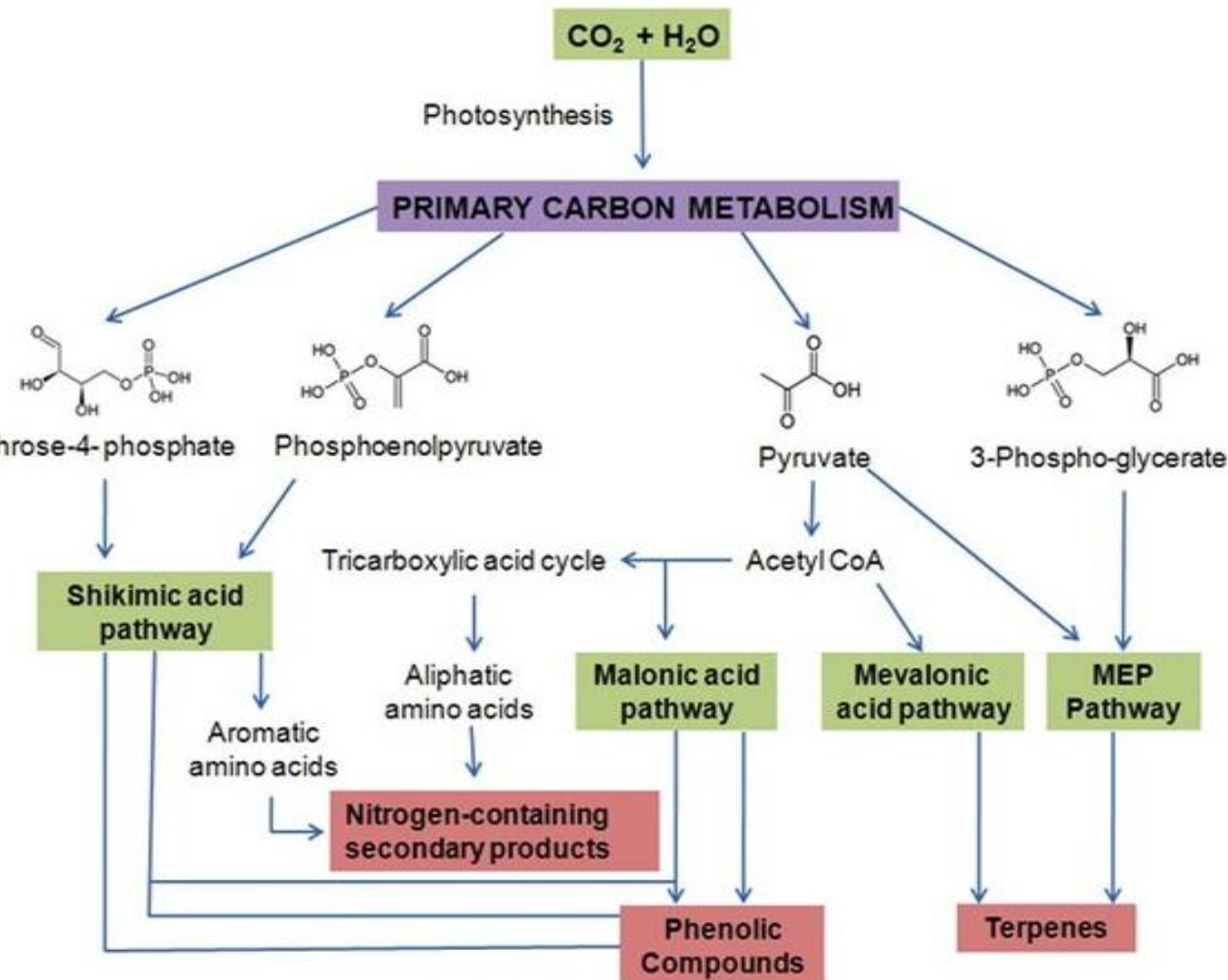

Figure 2. Layout of drug discovery process: from nature to market.

5. Applied Methods for the Isolation and Structure Elucidation of Metabolites: Improved Biomass and Secondary Metabolite in Culture Environment

To obtain highly concentrated secondary metabolites, supporting factors, such as media components, physical factors ( $\mathrm{pH}$, temperature, light, etc.) and plant growth regulators, play an important role $[28,29]$. The selection of source explants as inoculums to the production is crucial, which should accumulate large number of secondary metabolites (Figure 3). Medium standardization is known to influence the biomass yield of secondary metabolites [30]; although [31] it is a widely used medium for the rapid growth of callus, it is not ideal for inducing secondary metabolites.

There have been several techniques developed to extract metabolites, including conventional and new hi-tech techniques. Conventional techniques include using organic solvents, such as hexane, methanol, acetone, ethanol, etc., and/or water, and the procedure is carried out at room temperature, which mostly allows for the dissolution of the soluble metabolites excreted into the solvent during the growth processes. This process relies on the combined action of heat, mixing and on the extracting capacity of the solvents [32], which are necessary for the differentiation of active components by using the appropriate solvents. Several novel extraction methods, such as microwave-assisted extraction (MAE), ultrasound-assisted extraction (UAE), pressurized liquid extraction (PLE) and supercritical fluid extraction (SFE), have been developed. These techniques reduce the volume of the solvent, the extraction time, and improve yield [33]. 


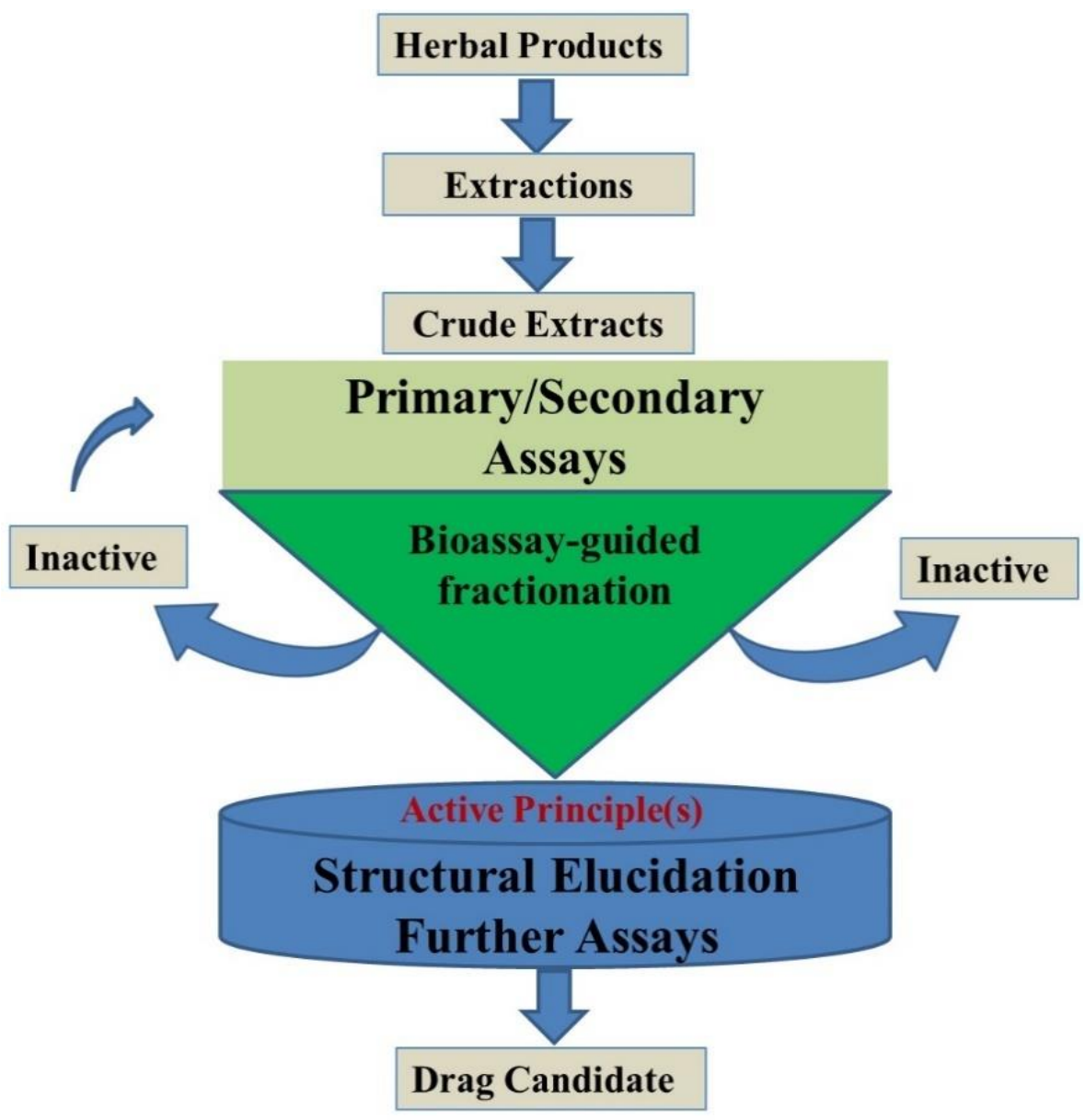

Figure 3. Steps required for the characterization of a bioactive compound from natural sources.

\section{Identification and Characterization of Techniques}

To identify the desired secondary metabolites, the pure compound is separated from the mixture and identified through chromatographic and non-chromatographic techniques. Chromatographic techniques are used in both the separation and/or identification of the active components in a mixture. Chromatographic techniques are used on an industrial scale and/or for academic purposes to separate and purify the products in various syntheses. There are various chromatography techniques, from the simplest thin-layer chromatography (TLC) to advanced gas chromatography and liquid chromatography with mass spectroscopy [14,34].

\section{The Role of Plant-Derived Natural Products in Drug Innovation and Plants as Sources of Bioactive Natural Medicinal Products}

A plant product ranges from a simple skeleton to far more complex molecules that are even not possible to synthesize in laboratory conditions. These metabolic derivatives have highly specific activities via a unique mechanism (Figure 4). These are the reasons why plant metabolites are potentially important in drug development, especially nowadays, when in-depth knowledge is emerging through the human genome sequencing of multiple new molecular targets that have been tested for their potential use as drug targets [35]. The isolation and discovery of quinine became a landmark in the field of pharmacognosy [36] and since then, many active ingredients of plant source have been identified and characterized. 


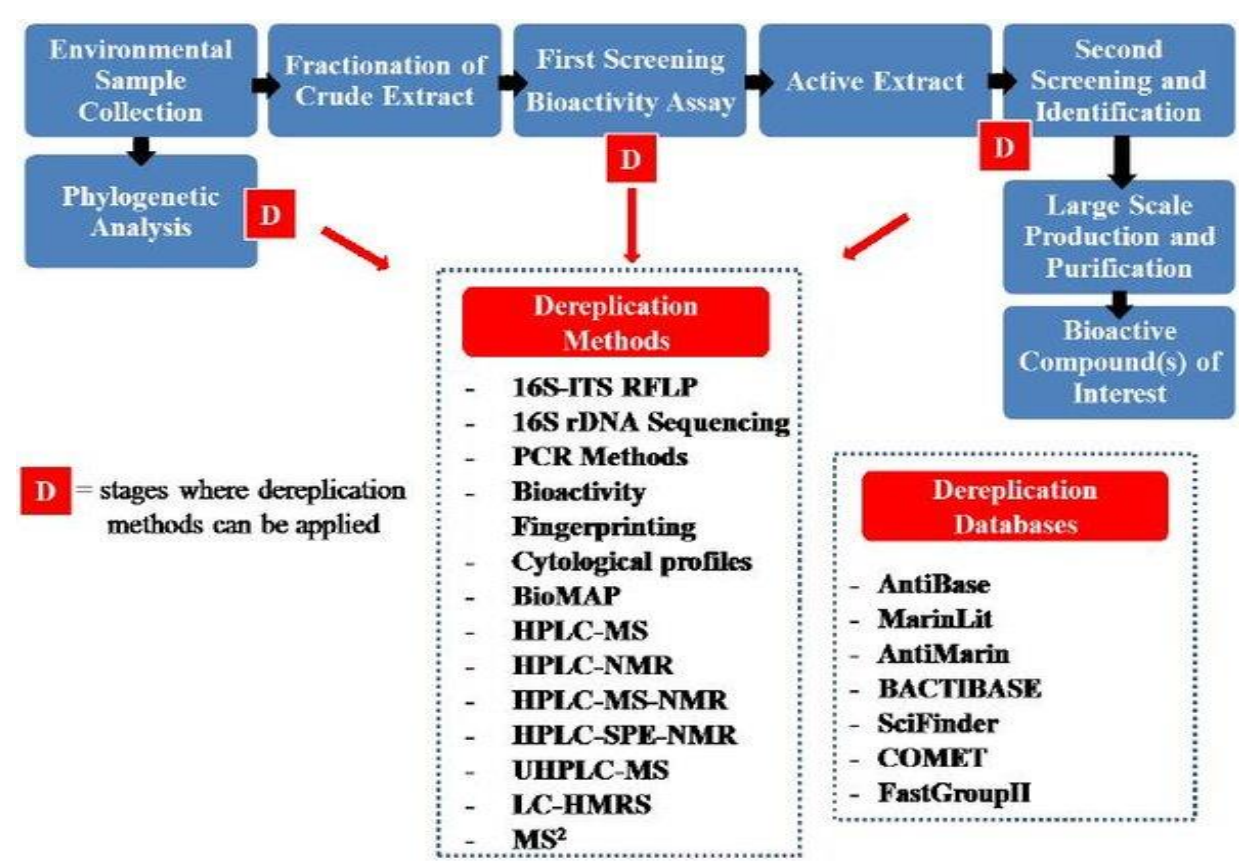

Figure 4. The various steps and techniques required during the characterization of plant products.

\section{Function and Use of Secondary Metabolites}

In the early days, plant extracts were considered to have the function of waste or detoxification products [37]. Until then, most research efforts had not been initiated and research started once technology was used to explore the applications of secondary metabolites for their intended biological functions in nature. The functions of the vast majority of secondary metabolites, however, are still unknown. Secondary metabolites are most importantly used as pharmaceuticals, food additives and cosmetics ingredients.

\section{Current Plant-Derived Natural Products in Therapeutic Use}

There are various plant derivatives of natural products that are in regular use as therapeutic agents (Table 1).

Table 1. Important plants species and their metabolites with medicinal effects.

\begin{tabular}{|c|c|c|c|}
\hline Drug & Source & Target Disease & Reference \\
\hline Metformin & Galega officinalis & Anti-diabetic & [38] \\
\hline Galantamine & Galanthus woronowii & Alzheimer's disease & [39] \\
\hline Artemisinin & Artemisia annua & Malignant cerebral malaria & [36] \\
\hline Paclitaxel & Taxus brevifolia & Antimitotic agent-Various cancer & [40] \\
\hline Calanolide A & Calophyllum lanigerum, & Type-1 HIV & [35] \\
\hline Crude extract & Sarcotheca griffithii & Cough & [41] \\
\hline Crude extract & Piper retrofractum & $\begin{array}{l}\text { Fever, hypotension, abdominal pain, } \\
\text { anthelmintic }\end{array}$ & {$[42,43]$} \\
\hline $\begin{array}{c}\text { Crude extract (acrylamides and } \\
\text { phaeophytins) }\end{array}$ & Talinum triangulare & Cuts, wound, scabies and peptic ulcer & {$[44,45]$} \\
\hline $\begin{array}{c}\text { Crude extract (monoterpenes and } \\
\text { sesquiterpenes) }\end{array}$ & Amorpha fruticosa & Antibacterial, insecticidal, cytotoxic & [46-48] \\
\hline Crude extract & Alpinia officinarum & Anti-microbial and anti-inflammatory & [49] \\
\hline
\end{tabular}


Table 1. Cont.

\begin{tabular}{|c|c|c|c|}
\hline Drug & Source & Target Disease & Reference \\
\hline Crude extract & Ocimum Basilicum & Anti-inflammatory activity & [50] \\
\hline Crude extract & Costus pictus & anti-diabetic & [51] \\
\hline Isopropanol & Synthesis & Used as alcohol & [11] \\
\hline Isovaleric acid & Essential oils & $\begin{array}{l}\text { Anticonvulsant and used in } \\
\text { perfumery }\end{array}$ & {$[52]$} \\
\hline Limonene & Essential oils & $\begin{array}{c}\text { Fragrant, anti-carcinogenic and } \\
\text { bacterial }\end{array}$ & {$[53,54]$} \\
\hline Linalool & Essential oils & $\begin{array}{c}\text { Antibacterial, effects center nervous } \\
\text { system }\end{array}$ & {$[55,56]$} \\
\hline Phytoalexins & At sire of infections in plants & $\begin{array}{l}\text { Anti-antimicrobial, anti-cancer and } \\
\text { anti-oxidative }\end{array}$ & {$[55,57]$} \\
\hline Gibberellin & Gibberella fujikuroi & $\begin{array}{l}\text { Elongation of plant and promotes } \\
\text { growth }\end{array}$ & {$[58,59]$} \\
\hline Brassinosteroids & Brassica napus, Lychnis viscaria & Plant protection & {$[60,61]$} \\
\hline Sterols & $\begin{array}{l}\text { Naturally found in plants, fungi } \\
\text { and animals }\end{array}$ & $\begin{array}{l}\text { Medicinal effect and nutritional } \\
\text { supplements }\end{array}$ & {$[60,61]$} \\
\hline Carotenoids & $\begin{array}{l}\text { Chloroplasts, carrots, and } \\
\text { chromoplasts of plants }\end{array}$ & Antioxidants & {$[60,61]$} \\
\hline Atropine & $\begin{array}{l}\text { Atropa belladonna, datura } \\
\text { stramonium }\end{array}$ & $\begin{array}{l}\text { Adversary of muscarinic } \\
\text { acetylcholine receptors, anti-myopia } \\
\text { effects, anti-cholinergic, }\end{array}$ & {$[62,63]$} \\
\hline Berberine & Berberis species & $\begin{array}{l}\text { Anti-bacterial, antiviral, } \\
\text { anti-inflammatory, anti-cancer and } \\
\text { anti-diabetic }\end{array}$ & {$[56,64,65]$} \\
\hline Codeine & Papaver somniferum & $\begin{array}{l}\text { Analgesic, antidepressant, antitussive, } \\
\text { anti-diarrheal, sedative and hypnotic } \\
\text { properties }\end{array}$ & [66-69] \\
\hline Coniine & Conium macularum & Poisonous, neurotoxin & {$[70,71]$} \\
\hline Cytisine (baptitoxine, sophorine) & Cytisus laborinum & $\begin{array}{l}\text { Smoking cessation drug, } \\
\text { acetylcholine agonist }\end{array}$ & {$[72,73]$} \\
\hline Morphine & Papaver somniferum & $\begin{array}{l}\text { Edema, acute pulmonary and } \\
\text { shortness of breath }\end{array}$ & [74-76] \\
\hline Nicotine & Solanaceae & $\begin{array}{l}\text { Insecticide, anti-inflammatory and } \\
\text { stimulant, antiherbivore }\end{array}$ & [77-80] \\
\hline Quinine & Cinchona succirubra & Antimalarial & [81-84] \\
\hline Solanine & Solanum tuberosum & $\begin{array}{l}\text { Antifungal, ant pesticide, sedative, } \\
\text { anticonvulsant, anticarcinogenic, } \\
\text { anti-inflammatory }\end{array}$ & [85-88] \\
\hline Strychnine & Strychnos nux-vomica & Pesticide & [89-92] \\
\hline Thebaine (paramorphine) & Papaver bracteatum & Analgesic & {$[48,93-95]$} \\
\hline Tomatine & Tomato & $\begin{array}{c}\text { Anticancer, immune effects, } \\
\text { antifungal }\end{array}$ & [96-98] \\
\hline
\end{tabular}

Galantamine, an alkaloid originated from Galanthus woronowii, was approved for Alzheimer's disease treatment in 2001 by the FDA [15]. Galantamine inhibits acetylcholinesterase (AChE) and modulates nicotinic acetylcholine receptor (nAChR). Artemisinin from Artemisia annua has been used as an antimalarial drug for at least 2000 years. Artemisinin contains sesquiterpene lactone, which has bioactivity proven to treat malignant 
cerebral malaria caused by Plasmodium falciparum [36]. Artemisinin had poor bioavailability and so artemether, a derivative of artemisinin, was later developed with enhanced bioavailability $[35,40]$. Paclitaxel, isolated from Taxus brevifolia, a highly oxygenated tetracyclic diterpenoid, works as an antimitotic agent that inhibits the polymerization of tubulin to form microtubules. It is also used as an effective drug against ovarian and breast cancers and it has subsequently been approved for many other cancer treatments [40]. As the demand of paclitaxel is extremely high and its natural availability is limited, to meet the market demands several approaches have been used for its synthesis from starting materials, such as bacchatin III and 10-deacetylbacchatin III. In addition to chemical synthesis, it was also produced in high amounts using the second approach with cell cultures of Taxus plants. Calophyllum lanigerum was used to obtain Calanolide A, a dipyranocoumarin that works as a non-nucleoside reverse transcriptase inhibitor (NNRTi) of type-1 HIV and an inhibitor of AZT-resistant strains of HIV [35].

\section{Conclusions}

Plants contain secondary metabolites that are very specific and sometimes extremely toxic at a high concentration, and represent a fascinating library of bioactive compounds with a broad activity in the context of human cells, bacteria, fungi, and parasites. For economic reasons, the study of secondary metabolites has been the subject of intense efforts, contributing to the development of several areas of phytochemistry. This review article focuses on various aspects of secondary metabolites, production synthesis, and sources of medical products from plants sources.

So, this article will be a comprehensive reference for researchers or readers who are interested in secondary metabolites.

Author Contributions: B.M.T. and M.N.H. conceived, designed, wrote, reviewed and edited the final manuscript. All authors have read and agreed to the published version of the manuscript.

Funding: This research did not receive any specific grant from funding agencies from the public, commercial, or not-for-profit sectors.

Institutional Review Board Statement: Not applicable.

Informed Consent Statement: Not applicable.

Data Availability Statement: No new data were created in this study. Data sharing is not applicable.

Acknowledgments: The authors would like to thank Mustansiriyah University, Baghdad, Iraq and Shahjalal University of Science and Technology, Sylhet, Bangladesh for their support of the present work.

Conflicts of Interest: The authors declare no conflict of interest.

\section{References}

1. Sanchez, S.; Demain, A.L. Secondary Metabolites; American Society of Plant Physiologists: Derwood, MD, USA, 2000.

2. Bourgaud, F.; Gravot, A.; Milesi, S.; Gontier, E. Production of plant secondary metabolites: A historical perspective. Plant Sci. 2001, 161, 839-851. [CrossRef]

3. Tsao, R.; Yang, R.; Xie, S.; Sockovie, E.; Khanizadeh, S. Which polyphenolic compounds contribute to the total antioxidant activities of apple? J. Agric. Food Chem. 2005, 53, 4989-4995. [CrossRef] [PubMed]

4. Cragg, G.M.; Newman, D.J. Natural products: A continuing source of novel drug leads. Biochim. Et Biophys. Acta (BBA)-Gen. Subj. 2013, 1830, 3670-3695. [CrossRef] [PubMed]

5. Newman, D.J.; Cragg, G.M. Marine natural products and related compounds in clinical and advanced preclinical trials. J. Nat. Prod. 2004, 67, 1216-1238. [CrossRef]

6. Cragg, G.M.; Grothaus, P.G.; Newman, D.J. Impact of natural products on developing new anti-cancer agents. Chem. Rev. 2009, 109, 3012-3043. [CrossRef]

7. Weinberg, E.D. Trace-metal control of specific biosynthetic processes. Perspect. Biol. Med. 1962, 5, 432-445. [CrossRef]

8. Pawlikowski, T. Pollination activity of bees (Apoidea: Apiformes) visiting the flowers of Tilia cordata Mill. and Tilia tomentosa Moench in an urban environment. J. Apic. Sci. 2010, 54, 73-79.

9. Figueredo, A.C.; Barroso, J.G.; Pedro, L.G.; Scheffer, J.J. Factors affecting secondary metabolite production in plants: Volatile and essential oils. Flavour Fragr. J. 2008, 23, 213-226. [CrossRef] 
10. Ehrlich, P.R.; Holdren, J.P. Impact of population growth. Science 1971, 171, 1212-1217. [CrossRef]

11. Saxena, M.; Saxena, J.; Nema, R.; Singh, D.; Gupta, A. Phytochemistry of medicinal plants. J. Pharmacogn. Phytochem 2013, 1, 168-182.

12. Huang, W.Y.; Cai, Y.Z.; Zhang, Y. Natural phenolic compounds from medicinal herbs and dietary plants: Potential use for cancer prevention. Nutr. Cancer 2009, 62, 1-20. [CrossRef] [PubMed]

13. Mabry, T.; Markham, K.R.; Thomas, M.B. The Systematic Identification of Flavonoids; Springer: Berlin/Heidelberg, Germany, 2012.

14. Harborne, A.J. Phytochemical Methods a Guide to Modern Techniques of Plant Analysis; Springer: Berlin/Heidelberg, Germany, 1998.

15. Dewick, P.M. Medicinal Natural Products: A Biosynthetic Approach; John Wiley \& Sons: Hoboken, NJ, USA, 2002.

16. Cseke, L.J.; Lu, C.R.; Kornfeld, A.; Kaufman, P.B.; Kirakosian, A. How and why these compounds are synthesized by plants. In Natural Products from Plants, 2nd ed.; Taylor \& Francis: Boca Raton, FL, USA, 2006; pp. 51-100.

17. Garcia-Brugger, A.; Lamotte, O.; Vandelle, E.; Bourque, S.; Lecourieux, D.; Poinssot, B.; Wendehenne, D.; Pugin, A. Early signaling events induced by elicitors of plant defenses. Mol. Plant-Microbe Interact. 2006, 19, 711-724. [CrossRef] [PubMed]

18. Medina, J.H.; Viola, H.; Wolfman, C.; Marder, M.; Wasowski, C.; Calvo, D.; Paladini, A.C. Overview-flavonoids: A new family of benzodiazepine receptor ligands. Neurochem. Res. 1997, 22, 419-425. [CrossRef] [PubMed]

19. Pelletier, S.W. The nature and definition of an alkaloid. Alkaloids Chem. Biol. Perspect 1983, 1, 1-31.

20. Oksman-Caldentey, K.M.; Inzé, D. Natural compounds derived from plants can be categorized into three different groups according to their final use in developing a drug. Trends Plant Sci. 2004, 9, 433-440. [CrossRef]

21. Zhu, Z.H.; Chao, C.J.; Lu, X.Y.; Xiong, Y.G. Paulownia in China: Cultivation and Utilization; International Development Research Centre: Ottawa, ON, Canada, 1986.

22. Gundlach, H.; Müller, M.J.; Kutchan, T.M.; Zenk, M.H. Jasmonic acid is a signal transducer in elicitor-induced plant cell cultures Proc. Natl. Acad. Sci. USA 1992, 89, 2389-2393. [CrossRef]

23. Mulabagal, V.; Tsay, H.S. Plant cell cultures-an alternative and efficient source for the production of biologically important secondary metabolites. Int. J. Appl. Sci. Eng. 2004, 2, 29-48.

24. Fett-Neto, A.G.; Melanson, S.J.; Sakata, K.; DiCosmo, F. Improved growth and taxol yield in developing calli of Taxus cuspidata by medium composition modification. Bio/Technol. 1993, 11, 731-734. [CrossRef]

25. Ellis, B.E.; Towers, G.H. Biogenesis of rosmarinic acid in Mentha. Biochem. J. 1970, 118, 291-297. [CrossRef]

26. Roberts, S.C.; Shuler, M.L. Large-scale plant cell culture. Curr. Opin. Biotechnol. 1997, 8, 154-159. [CrossRef]

27. Radman, R.; Saez, T.; Bucke, C.; Keshavarz, T. Elicitation of plants and microbial cell systems. Biotechnol. Appl. Biochem. 2003, 37, 91-102. [CrossRef] [PubMed]

28. Karuppusamy, S. A review on trends in production of secondary metabolites from higher plants by in vitro tissue, organ and cell cultures. J. Med. Plants Res. 2009, 3, 1222-1239.

29. Dörnenburg, H.; Frickinger, P.; Seydel, P. Plant cell-based processes for cyclotides production. J. Biotechnol. 2008, 135, 123-126. [CrossRef] [PubMed]

30. Seabrook, M.F. The Psychological Relationship between Dairy Cows and Dairy Cowmen and Its Implications for Animal Welfare. Int. J. Study Animal Probl. 1980, 1, 295-298.

31. Murashige, T.; Skoog, F. A revised medium for rapid growth and bio assays with tobacco tissue cultures. Physiol. Plant. 1962, 15, 473-497. [CrossRef]

32. De Castro, M.L.; Garcia-Ayuso, L.E. Soxhlet extraction of solid materials: An outdated technique with a promising innovative future. Anal. Chim. Acta 1998, 369, 1-10. [CrossRef]

33. Veer, V.; Gopalakrishnan, R. (Eds.) Herbal Insecticides, Repellents and Biomedicines: Effectiveness and Commercialization; Springer: Berlin/Heidelberg, Germany, 2016.

34. Sasidharan, S.; Chen, Y.; Saravanan, D.; Sundram, K.M.; Latha, L.Y. Extraction, isolation and characterization of bioactive compounds from plants' extracts. Afr. J. Tradit. Complementary Altern. Med. 2011, 8. [CrossRef]

35. Kumar, N.; Karambir, R.K. A comparative analysis of pmx, cx and ox crossover operators for solving traveling salesman problem. Int. J. Latest Res. Sci. Technol. 2012, 1, 98-101.

36. Phillipson, J.D. Phytochemistry and medicinal plants. Phytochemistry 2001, 56, 237-243. [CrossRef]

37. Jarvis, M.F.; Williams, M. Direct autoradiographic localization of adenosine A2 receptors in the rat brain using the A2-selective agonist, [3H]. CGS Eur. J. Pharmacol. 1989, 168, 243-246. [CrossRef]

38. Carlson, T.J.; King, S.R. From plant to patient: An ethnomedical approach to the identification of new drugs for the treatment of NIDDM. Diabetologia 1997, 40, 614-617.

39. Russo, P.; Frustaci, A.; Del Bufalo, A.; Fini, M.; Cesario, A. Multitarget drugs of plants origin acting on Alzheimer's disease. Curr. Med. Chem. 2013, 20, 1686-1693. [CrossRef] [PubMed]

40. Atanasov, A.G.; Waltenberger, B.; Pferschy-Wenzig, E.M.; Linder, T.; Wawrosch, C.; Uhrin, P.; Temml, V.; Wang, L.; Schwaiger, S.; Heiss, E.H.; et al. Discovery and resupply of pharmacologically active plant-derived natural products: A review. Biotechnol. Adv. 2015, 33, 1582-1614. [CrossRef] [PubMed]

41. Veldkamp, J.F. A revision of Sarcotheca Bl. and Dapania Korth.(Oxalidaceae). Blumea Biodivers. Evol. Biogeogr. Plants 1967, 15, 519-543.

42. Banerji, A.; Sarkar, M.; Datta, R.; Sengupta, P.; Abraham, K. Amides from Piper brachystachyum and Piper retrofractum. Phytochemistry 2002, 59, 897-901. [CrossRef] 
43. Muharini, R.; Liu, Z.; Lin, W.; Proksch, P. New amides from the fruits of Piper retrofractum. Tetrahedron Lett. 2015, 56, 2521-2525. [CrossRef]

44. Onwurah, N.N.; Eke, I.G.; Anaga, A.O. Antiulcer Properties of Aqueous Extract of Talinum Triangulare Leaves in Experimentally Induced Gastric Ulceration in Mice. Asian J. Pharm. Biol. Res. (AJPBR) 2013, 3, 4-7.

45. Lawal, I.O.; Uzokwe, N.E.; Ladipo, D.O.; Asinwa, I.O.; Igboanugo, A.B. Ethnophytotherapeutic information for the treatment of high blood pressure among the people of Ilugun, Ilugun area of Ogun State, south-west Nigeria. Afr. J. Pharm. Pharmacol. 2009, 3, 222-226.

46. López-Grimau, V.; Gutierrez, M.C. Decolourisation of simulated reactive dyebath effluents by electrochemical oxidation assisted by UV light. Chemosphere 2006, 62, 106-112. [CrossRef]

47. Mitscher, L.A.; Park, Y.H.; Alshamma, A.; Hudson, P.B.; Haas, T. Amorfrutin A and B, bibenzyl antimicrobial agents from Amorpha fruticosa. Phytochemistry 1981, 20, 781-785. [CrossRef]

48. Lee, H.J.; Kang, H.Y.; Kim, C.H.; Kim, H.S.; Kwon, M.C.; Kim, S.M.; Shin, I.S.; Lee, H.Y. Effect of new rotenoid glycoside from the fruits of Amorpha fruticosa LINNE on the growth of human immune cells. Cytotechnology 2006, 52, 219-226. [CrossRef] [PubMed]

49. Subramanian, K.; Selvakkumar, C.; Vinaykumar, K.S.; Goswami, N.; Meenakshisundaram, S.; Balakrishnan, A.; Lakshmi, B.S. Tackling multiple antibiotic resistance in enteropathogenic Escherichia coli (EPEC) clinical isolates: A diarylheptanoid from Alpinia officinarum shows promising antibacterial and immunomodulatory activity against EPEC and its lipopolysaccharideinduced inflammation. Int. J. Antimicrob. Agents 2009, 33, 244-250. [PubMed]

50. Selvakkumar, C.; Gayathri, B.; Vinaykumar, K.S.; Lakshmi, B.S.; Balakrishnan, A. Potential anti-inflammatory properties of crude alcoholic extract of Ocimum basilicum L. in human peripheral blood mononuclear cells. J. Health Sci. 2007, 53, 500-505. [CrossRef]

51. Shilpa, K.; Sangeetha, K.N.; Muthusamy, V.S.; Sujatha, S.; Lakshmi, B.S. Probing key targets in insulin signaling and adipogenesis using a methanolic extract of Costus pictus and its bioactive molecule, methyl tetracosanoate. Biotechnol. Lett. 2009, 31, 1837-1841. [CrossRef]

52. Elson, C.E.; Maltzman, T.H.; Boston, J.L.; Tanner, M.A.; Gould, M.N. Anti-carcinogenic activity of d-limonene during the initiation and promotion/progression stages of DMBA-induced rat mammary carcinogenesis. Carcinogenesis 1988, 9, 331-332. [CrossRef]

53. Espina, L.; Gelaw, T.K.; de Lamo-Castellvi, S.; Pagán, R.; Garcia-Gonzalo, D. Mechanism of bacterial inactivation by (+)-limonene and its potential use in food preservation combined processes. PLoS ONE 2013, 8, e56769. [CrossRef] [PubMed]

54. Coelho, V.; Mazzardo-Martins, L.; Martins, D.F.; Santos, A.R.; da Silva Brum, L.F.; Picada, J.N.; Pereira, P. Neurobehavioral and genotoxic evaluation of (-)-linalool in mice. J. Nat. Med. 2013, 67, 876-880. [CrossRef] [PubMed]

55. Taniguchi, S.; Hosokawa-Shinonaga, Y.; Tamaoki, D.; Yamada, S.; Akimitsu, K.; Gomi, K. Jasmonate induction of the monoterpene linalool confers resistance to rice bacterial blight and its biosynthesis is regulated by JAZ protein in rice. Plant Cell Environ. 2014, 37, 451-461. [CrossRef] [PubMed]

56. Zhang, Q.; Cai, L.; Zhong, G.; Luo, W. Simultaneous determination of jatrorrhizine, palmatine, berberine, and obacunone in Phellodendri Amurensis Cortex by RP-HPLC. China J. Chin. Mater. Med. (Zhongguo Zhongyao Zazhi) 2010, 35, 2061-2064.

57. Zhang, J.; Schurr, U.; Davies, W.J. Control of stomatal behaviour by abscisic acid which apparently originates in the roots. J. Exp. Bot. 1987, 38, 1174-1181. [CrossRef]

58. Hakoshima, T.; Murase, K.; Hirano, Y.; Sun, T. Gibberellin Perception by the Gibberellin Receptor and its Effector Recognition Nihon Kessho Gakkaishi 2010, 52, 37-41. [CrossRef]

59. Sun, T.P. Gibberellin-GID1-DELLA: A pivotal regulatory module for plant growth and development. Plant Physiol. 2010, 154, 567-570. [CrossRef] [PubMed]

60. Hacham, Y.; Holland, N.; Butterfield, C.; Ubeda-Tomas, S.; Bennett, M.J.; Chory, J.; Savaldi-Goldstein, S. Brassinosteroid perception in the epidermis controls root meristem size. Development 2011, 138, 839-848. [CrossRef] [PubMed]

61. Iwu, M.M. African Medicinal Plants; CRC Press: Boca Raton, FL, USA, 1993.

62. McBrien, N.A.; Stell, W.K.; Carr, B. How does atropine exert its anti-myopia effects? Ophthalmic Physiol. Opt. 2013, 33, 373-378. [CrossRef]

63. Gu, L.; Li, N.; Gong, J.; Li, Q.; Zhu, W.; Li, J. Berberine ameliorates intestinal epithelial tight-junction damage and down-regulates myosin light chain kinase pathways in a mouse model of endotoxinemia. J. Infect. Dis. 2011, 203, 1602-1612. [CrossRef]

64. Agyapong, V.I.; Singh, K.; Savage, M.; Thekiso, T.B.; Finn, M.; Farren, C.K.; McLoughlin, D.M. Use of codeine-containing medicines by Irish psychiatric inpatients before and after regulatory limitations on their supply. Ir. J. Psychol. Med. 2013, 30, 7-12. [CrossRef]

65. Kim, J.B.; Yu, J.H.; Ko, E.; Lee, K.W.; Song, A.K.; Park, S.Y.; Shin, I.; Han, W.; Noh, D.Y. The alkaloid Berberine inhibits the growth of Anoikis-resistant MCF-7 and MDA-MB-231 breast cancer cell lines by inducing cell cycle arrest. Phytomedicine 2010, 17, 436-440. [CrossRef]

66. Simera, M.; Poliacek, I.; Jakus, J. Central antitussive effect of codeine in the anesthetized rabbit. Eur. J. Med. Res. 2010, 15, 1-5. [CrossRef]

67. Smith, J.; Owen, E.; Earis, J.; Woodcock, A. Effect of codeine on objective measurement of cough in chronic obstructive pulmonary disease. J. Allergy Clin. Immunol. 2006, 117, 831-835. [CrossRef]

68. Vree, T.B.; Van Dongen, R.T.; Koopman-Kimenai, P.M. Codeine analgesia is due to codeine-6-glucuronide, not morphine. Int. J. Clin. Pract. 2000, 54, 395-398. 
69. Mody, N.V.; Henson, R.; Hedin, P.A.; Kokpol, U.; Miles, D.H. Isolation of the insect paralyzing agent coniine from Sarracenia flava. Experientia 1976, 32, 829-830. [CrossRef]

70. Panter, K.E.; Welch, K.D.; Gardner, D.R.; Green, B.T. Poisonous plants: Effects on embryo and fetal development. Birth Defects Res. Part C Embryo Today Rev. 2013, 99, 223-234. [CrossRef]

71. Hajek, P.; McRobbie, H.; Myers, K. Efficacy of cytisine in helping smokers quit: Systematic review and meta-analysis. Thorax 2013, 68, 1037-1042. [CrossRef] [PubMed]

72. Porreca, F.; Cowan, A.; Raffa, R.B.; Tallarida, R.J. Ketazocines and morphine: Effects on gastrointestinal transit after central and peripheral administration. Life Sci. 1983, 32, 1785-1790. [CrossRef]

73. West, R.; Zatonski, W.; Cedzynska, M.; Lewandowska, D.; Pazik, J.; Aveyard, P.; Stapleton, J. Placebo-controlled trial of cytisine for smoking cessation. N. Engl. J. Med. 2011, 365, 1193-1200. [CrossRef] [PubMed]

74. Rozov-Ung, I.; Mreyoud, A.; Moore, J.; Wilding, G.E.; Khawam, E.; Lackner, J.M.; Semler, J.R.; Sitrin, M.D. Detection of drug effects on gastric emptying and contractility using a wireless motility capsule. BMC Gastroenterol. 2014, 14, 1-6. [CrossRef]

75. Takita, K.; Herlenius, E.; Yamamoto, Y.; Lindahl, S.G. Effects of neuroactive substances on the morphine-induced respiratory depression; an in vitro study. Brain Res. 2000, 884, 201-205. [CrossRef]

76. Clarke, P.B.; Fu, D.S.; Jakubovic, A.L.; Fibiger, H.C. Evidence that mesolimbic dopaminergic activation underlies the locomotor stimulant action of nicotine in rats. J. Pharmacol. Exp. Ther. 1988, 246, 701-708.

77. Gandhi, P.T. Novel Nicotine Derivatives. U.S. Patent 20130123106, 16 May 2013.

78. Velu, G.; Palanichamy, V.; Rajan, A.P. Phytochemical and pharmacological importance of plant secondary metabolites in modern medicine. In Bioorganic Phase in Natural Food: An Overview; Springer: Cham, Switzerland, 2018; pp. $135-156$.

79. Rhoades, D.F.; Cates, R.G. Toward a general theory of plant antiherbivore chemistry. In Biochemical Interaction between Plants and Insects; Springer: Boston, MA, USA, 1976; pp. 168-213.

80. Achan, J.; Talisuna, A.O.; Erhart, A.; Yeka, A.; Tibenderana, J.K.; Baliraine, F.N.; Rosenthal, P.J.; D'Alessandro, U. Quinine, an old anti-malarial drug in a modern world: Role in the treatment of malaria. Malar. J. 2011, 10, 1-2. [CrossRef]

81. Adnyana, I.K.; Sukandar, E.Y.; Setiawan, F.; Christanti, Y. Efficacy and safety O-desmethyl quinine compare to quinine for nocturnal leg cramp. J. Med. Sci. (Pak.) 2013, 13, 819-823. [CrossRef]

82. El-Tawil, S.; Al Musa, T.; Valli, H.; Lunn, M.P.; Brassington, R.; El-Tawil, T.; Weber, M. Quinine for muscle cramps. Cochrane Database Syst. Rev. 2015, 4, CD005044. [CrossRef] [PubMed]

83. Clifford, M.; Leah, M.; Charles, N. Antiepileptic properties of Quinine: A systematic review. Ann. Neurosci. 2012, 19, 14. [PubMed]

84. Fewell, A.M.; Roddick, J.G. Interactive antifungal activity of the glycoalkaloids $\alpha$-solanine and $\alpha$-chaconine. Phytochemistry 1993, 33, 323-328. [CrossRef]

85. Lu, M.K.; Shih, Y.W.; Chien, T.T.; Fang, L.H.; Huang, H.C.; Chen, P.S. $\alpha$-Solanine inhibits human melanoma cell migration and invasion by reducing matrix metalloproteinase-2/9 activities. Biol. Pharm. Bull. 2010, 33, 1685-1691. [CrossRef] [PubMed]

86. Kenny, O.M.; McCarthy, C.M.; Brunton, N.P.; Hossain, M.B.; Rai, D.K.; Collins, S.G.; Jones, P.W.; Maguire, A.R.; O’Brien, N.M. Anti-inflammatory properties of potato glycoalkaloids in stimulated Jurkat and Raw 264.7 mouse macrophages. Life Sci. 2013, 92, 775-782. [CrossRef]

87. Mohsenikia, M.; Alizadeh, A.M.; Khodayari, S.; Khodayari, H.; Karimi, A.; Zamani, M.; Azizian, S.; Mohagheghi, M.A. The protective and therapeutic effects of alpha-solanine on mice breast cancer. Eur. J. Pharm. 2013, 718, 1-9. [CrossRef] [PubMed]

88. Bonjoch, J.; Solé, D. Synthesis of strychnine. Chem. Rev. 2000, 100, 3455-3482. [CrossRef]

89. Buckingham, J. Bitter Nemesis-The Intimate History of Strychnine; CRC Press: Boca Raton, FL, USA, 2007.

90. Do Pham, D.D.; Kelso, G.F.; Yang, Y.; Hearn, M.T. Studies on the oxidative N-demethylation of atropine, thebaine and oxycodone using a Fe III-TAML catalyst. Green Chem. 2014, 16, 1399-1409. [CrossRef]

91. Jensen, A.A.; Gharagozloo, P.; Birdsall, N.J.; Zlotos, D.P. Pharmacological characterisation of strychnine and brucine analogues at glycine and $\alpha 7$ nicotinic acetylcholine receptors. Eur. J. Pharm. 2006, 539, 27-33. [CrossRef]

92. Umukoro, S.; Omogbiya, I.A.; Eduviere, A.T. Evaluation of the effect of jobelyn ${ }^{\circledR}$ on chemoconvulsants-induced seizure in mice. Basic Clin. Neurosci. 2013, 4, 125.

93. In, H.J.; Young, S.K.; Kwang, Y.C.; Keun, J.K. Unexpected effect of fluorine in diels-alder reaction of 2-fluoroacrolein with thebaine. Bull. Korean Chem. Soc. 1990, 11, 178-179.

94. Fist, A.J.; Byrne, C.J.; Gerlach, W.L. Papaver Somniferum Strain with High Concentration of Thebaine and Oripavine. U.S. Patent 6,067,749, 30 May 2000.

95. Heal, K.G.; Taylor-Robinson, A.W. Tomatine adjuvantation of protective immunity to a major pre-erythrocytic vaccine candidate of malaria is mediated via CD8+ T cell release of IFN- $\gamma$. J. Biomed. Biotechnol 2010, 2010, 834326. [CrossRef] [PubMed]

96. Morrow, W.J.; Yang, Y.W.; Sheikh, N.A. Immunobiology of the Tomatine adjuvant. Vaccine 2004, 22, 2380-2384. [CrossRef] [PubMed]

97. Gao, S.; Hu, M. Bioavailability challenges associated with development of anti-cancer phenolics. Mini Rev. Med. Chem. 2010, 10, 550-567. [CrossRef]

98. Tomsik, P.; Micuda, S.; Sucha, L.; Cermakova, E.; Suba, P.; Zivny, P.; Mazurova, Y.; Knizek, J.; Niang, M.; Rezacova, M. The anticancer activity of alpha-tomatine against mammary adenocarcinoma in mice. Biomed. Pap. 2013, 157, 153-161. [CrossRef] [PubMed] 